\title{
Corrigendum
}

\section{Infectious bronchitis virus: evolution and vaccination}

\author{
S. UMAR, M.A.A. SHAH, M.T. MUNIR, U. AHSAN and K. KABOUDI
}

doi:10.1017/S0043933915002706. Published online by Cambridge University Press, 1 January 2016.

The authors regret that an error was made in the author affiliations of the published paper (Umar et al., 2016). When originally published the affiliation of 'National Veterinary School of Toulouse, France' was added in error to the author information for S. Umar. The authors would like to apologize for this mistake.

\section{References}

UMAR, S., SHAH, M.A.A., MUNIR, M.T., AHSAN, U. and KABOUDI, K. (2016) Infectious bronchitis virus: Evolution and vaccination. World's Poultry Science Journal 72: 49-60. doi:10.1017/ S0043933915002706. 